\title{
Renal Physiological Status of Sickle Cell Anemic Patients, District Amravati, MS India
}

\author{
Andhale RB ${ }^{1}$, Sangita Lodha ${ }^{2}$ and Varsha Wankhade ${ }^{1 *}$ \\ ${ }^{1}$ Department of Zoology's University of Pune, Pune, Maharashtra, India \\ ${ }^{2}$ Thalassemia Center, Jankalyan Blood Bank, Nashik, Maharashtra, India
}

\begin{abstract}
Sickle cell anemia is a genetic disorder caused by mutation in globin gene in which serious morbidity and mortality can be resulted. Patients with Sickle cell anemia need regular blood transfusion. Anemia may cause physiological failure of various organ systems. Accumulation of iron due to hemolysis can cause damage to various organs. In the present study, few biochemical indices for renal tubular functions were investigated. In total 67 urine samples from sickle cell anemia patients were studied. Samples were estimated for markers such as Creatinine, Protein, Urea, Sodium $\left(\mathrm{Na}^{+}\right)$, Potassium $\left(\mathrm{K}^{+}\right)$; Uric acid and Specific gravity and Urea. It was observed that many parameters were in abnormal range indicating impaired renal function.
\end{abstract}

Keywords: Sickle cell anemia; Renal function; Urinalysis

\section{Introduction}

Sickle Cell Anemia (SCA) affects most of the tissue of the body. In later stages of this disorder renal dysfunction causes sickle nephropathy. Sickle cell anemia is characterized by sickled erythrocytes, which causes microinfarct, ischemia, decreased medullary blood flow and papillary necrosis [1]. SCA results in both anatomical alterations and disturbances in renal function. Most of the sickle cell anemic patients have large kidneys, which may be due to increased renal blood volume [2].

Every year over 300,000 babies who are homozygous for SCA are born worldwide. The majority of which are in middle and low income countries. About $5 \%$ of the world population is the carriers of gene for sickle cell anemia. Percentage of the disease is high in Asia, the Mediterranean basis, the Middle East and Africa [3]. Few studies reported high mortality rate in children with sickle cell disease during the first five years of life due to infection and splenic sequestration [4-6]. Early diagnosis and inclusive care can reduce mortality and morbidity rate significantly in children with sickle cell disease [7-10]. Prophylaxis with penicillin in preventing Streptococcus pneumonia septicemia were confirmed to be beneficial in a blinded, randomized, control study and offered a solid scientific rationale for new born screening [11].

The defect in urine concentrating ability in sickle cell trait is believed to be the result of intracellular polymerization of $\mathrm{HbS}$ in erythrocytes that causes occlusion of smaller capillaries in the vasa recta of the renal medulla. The severity of the defect in concentration of urine might be linked to the percentage of sickling phenomenon of erythrocytes. Gupta et al. reported correlation between urine concentrating ability and the percentage of sickled hemoglobin, which was maximum in the individuals with normal alpha-globin genotype and minimum in those homozygous for the deletion [12]

\section{Methodology}

\section{Study area and population}

The study population consisted of 67 randomized sub $\neg$ jects with Sickle cell anemia from the district Amravati, MS, India. This study was approved by Institutional Human Ethics Committee. The study protocol and laboratory examinations were discussed with patients and their parents' and written consents were taken. The mean age of the participants was 20.45 years. All selected participants were earlier diagnosed for sickle cell anemia.

\section{Urine collection and study of urine parameters}

Collection of sample: Clean catch urine samples were collected. A standard spontaneous voiding procedure was followed to collect urine samples from the participants [13]. Urine collection was done at noon to avoid contamination of urine by contents of urethra or vagina and therefore its constituents are more likely to reflect kidney origin. First void samples were also collected as they are informative and concentrated samples. Urine samples were collected in a sterile, labeled bottle containing $4 \%$ formaldehyde. Once urine was collected, it was transported to the laboratory immediately in an ice bag. All the analysis was performed within a week $[14,15]$.

Physical observations of urine: Urine sample was observed for colour pattern, turbidity etc. $\mathrm{pH}$ was measured by $\mathrm{pH}$ Tutor (Make:Oakton) and Specific gravity by Urinometer (Make:Davinder Glass works, Delhi, India).

Biochemical examination of urine of SCA: Biochemical estimations such as estimation of Potassium ion, Sodium ion, Urea, Creatinine, Uric Acid and bilirubin were performed using commercially available kits.

Statistical analysis: Comparative student t-test was calculated. P-value of $<0.05$ was considered as statistically significant value. Data was presented in arithmetic mean; standard deviation and standard error were calculated by SPSS and Mega stat software.

\section{Results}

It was observed that many urine parameters in sickle cell anemia patients are not in the normal range. Urine $\mathrm{pH}$ was $6.57+0.523$ and value

*Corresponding author: Varsha Wankhade, Department of Zoology's University of Pune, Pune, Maharashtra, India, Tel: 9763968646; E-mail: varsha3w@unipune.ac.in

Received October 30, 2013; Accepted December 24, 2013; Published December 29, 2013

Citation: Andhale RB, Sangita Lodha, Wankhade V (2013) Renal Physiologica Status of Sickle Cell Anemic Patients, District Amravati, MS India. J Blood Disorders Transf 5: 188. doi: 10.4172/2155-9864.1000188

Copyright: (c) 2013 Andhale RB, et al. This is an open-access article distributed under the terms of the Creative Commons Attribution License, which permits unrestricted use, distribution, and reproduction in any medium, provided the original author and source are credited. 
of specific gravity was $1.00+0.220$ which were not significantly altered in patients. Urine creatinine level was $0.36+2.41 \mathrm{mg} / \mathrm{dl}$, urine urea was $182.72+10.4 \mathrm{mg} / \mathrm{dl}$ which was significantly high in the patients; urine sodium value was $217.85 \pm 9.864 \mathrm{mmol} / \mathrm{l}$; urine potassium level was $34.86+4.472 \mathrm{mmol} / \mathrm{l}$; urine uric acid was $1.44+0.317 \mathrm{mg} / \mathrm{dl}$. Protein level is found to be significantly high in sickle cell anemic patients than normal participants. Urine mean protein value in normal was $0.03 \pm$ 0.556 while in SCA was $1.832 \pm 0.203 \mathrm{mg} / \mathrm{ml}$ of urine. The values of various biochemical parameters of urine in sickle cell anemia are shown in Table 1.

In majority of the sickle cell urine, biochemical and physical parameters are found to be altered. This may be due to the side effects of chelating drug, deposition of iron in renal tissue, renal infarction due to increased platelet aggregation, decreased serum level of protein and anti-thrombin III [16]. Urine creatinine level $(0.36+2.41 \mathrm{mg} / \mathrm{dl})$ and urine urea $(182.72+10.41 \mathrm{mg} / \mathrm{dl})$ were significantly higher in the patients compared to the normal participants.

It indicates kidney damage and affected glomerular filtration [17]. Urea level was significantly greater indicating nephron damage and impairment of tubular re absorption and secretion processes. Uric acid in urine of Sickle cell disease and sickle cell trait was significantly less than normal. Level of uric acid in sickle cell patients was $1.44 \pm 0.317$ $\mathrm{mg} / \mathrm{dl}$ of urine.

Potassium ion concentration in sickle cell patients was $34.86+4.472$ $\mathrm{mmol} / \mathrm{dl}$ and in normal participants it was $73.35+4.129 \mathrm{mmol} / \mathrm{dl}$ of urine. Abnormal values of potassium in the urine of sickle cell anemic indicate the derangement of production of adrenocortical or pituitary hormones [17]. Pituitary gland and adrenal cortex function may be affected due to hypoxic condition in SCA.

Sodium ion concentration in the urine of Sickle cell disease was less than in the urine of normal persons. Sodium ion concentration in sickle cell patients was $217.85+9.864$ and in normal participants it was $236.16+17.685 \mathrm{mmol} / \mathrm{dl}$ of urine. The level of Urea is significantly greater in sickle cell anemic patients as compared to normal. Mean value of Urea in urine of SCA was $182.72+10.41 \mathrm{mg} / 100 \mathrm{ml}$ of urine while in normal participants the value was found to be $42.15+15.73 \mathrm{mg} / 100 \mathrm{ml}$ of urine. Thus value of urea in SCA indicates nephron damage and thus tubular reabsorption and secretion processes at nephron are affected in such persons. The level of creatinine is significantly less as compared to normal. Mean value of creatinine concentration in urine of SCA was $0.36 \mathrm{mg} / \mathrm{dl}$ of urine while in normal participants the value was found to be $1.143 \mathrm{mg}$ in $100 \mathrm{ml}$ of urine. From above data it may be suspected that kidney is damaged in SCA and glomerular filtration is highly affected [17].

\begin{tabular}{|c|c|c|c|}
\hline Sr No & Urine Parameter & SCA +SE & Control+SE \\
\hline 1 & $\mathrm{pH}$ & $6.57+0.523$ & $5.86+0.435$ \\
\hline 2 & Specific gravity & $1.00+0.220$ & $1.01+0.346$ \\
\hline 3 & Uric acid in $\mathrm{mg} / \mathrm{dl}$ & $1.44+0.317$ & $1.67+1.054$ \\
\hline 4 & Potassium in $\mathrm{mmol} / \mathrm{l}$ & $34.86+4.472^{* *}$ & $73.35 \pm 4.129$ \\
\hline 5 & Urea $\mathrm{mg} / \mathrm{dl}$ & $182.72+10.41^{* *}$ & $42.15+15.73$ \\
\hline 7 & Creatinine in $\mathrm{mg} / \mathrm{dl}$ & $0.36+2.41^{* *}$ & $1.14+2.56$ \\
\hline 8 & Sodium ion $\mathrm{mmol} / 100 \mathrm{ml}$ & $217.85 \pm 9.864 * *$ & $236.16 \pm 17.685$ \\
\hline 9 & Protein $\mathrm{mg} / \mathrm{ml}$ & $1.832 \pm 0.203^{* *}$ & $0.03 \pm 0.556$ \\
\hline
\end{tabular}

**=significant value. $P$ value is 0.05

Table 1: Comparative analysis of few biochemical parameters of urine of sickle cell anemia.

\section{Discussion}

SCA patients at district Amravati are under the threat of urinary tract infection, urinary tract inflammation, Glomerulonephritis, Interstitial nephritis, tubular necrosis, Pyelonephritis etc. [18]. On the basis of qualitative and quantitative microscopic analysis of urine of SCA it could be concluded that the kidney of such patients are under risk and suffering from various complications like nephrites, glomerular damage, hematouria etc. $[18,19]$.

The defect in urine concentrating ability in persons with sickle cell trait is thought to result from intracellular polymerization of $\mathrm{Hb}$ $S$ in erythrocytes. In the vasa recta of the renal medulla, this causes micro vascular occlusion. Percentage of sickle hemoglobin present in erythrocytes influences the severity of the pathophysiology. There is association between percentage of sickle hemoglobin and urine concentrating ability [20]. Microalbuminia is a marker of SCA glomerulopathy [21]. Sickle cell anemia is characterized by chronic organ failure; renal dysfunction in adults $(7,22)$. In $80 \%$ of aging SCA patient's renal failure and nephropathy is observed [22,23]. Oxidative peroxidation of lipids due to overload of iron leads to proximal tubular damage [24]. Kidney in sickle cell anemia (HbSS) is affected by hemodynamic changes of chronic anemia vaso-occlusion in the renal medulla $[25,26]$. There could be defects in potassium metabolism urinary acidification and urine concentrating capacity in SCA due to disruption of distal nephron and medullary function [27,28]. In all sickle cell disorders, kidney is unable to concentrate urine [29,30]. Chronic renal failure is the most common cause of death among HbSS above 40 years of age in some countries [26,31]. A 5 to $18 \%$ of SCD population patient is suffered from renal disorders [32]. Sickle cell hemoglobin C is affected by affected by renal failure [33]. There is mortality due to renal failure in SCD [34]. Renal failure is one of the main factors behind the mortality in SCD [35].

Nissenson and Port reported nephropathy in sickle cell patients in the U.S. [31]. Increased Glomerular Filtration Rate (GFR) and Renal Plasma Flow (RPF) have been well described in patients with sickle cell disease [36,37]. Progressive renal insufficiency in these patients has been ascribed to hyperfiltration-mediated sclerosis of the glomerular capillaries [38,39]. In the review article Pham et al. explained the association of the glomerular and tubular disorders with sickle cell nephropathy [40]. Proteinuria has been reported in 20 to $25 \%$ patients of SCA and drop off in the kidney function was observed in 5 to $30 \%$ of SCA patients $[35,41]$. Falk et al. reported the pathological features of sickle cell nephropathy in SCA [42].

\section{Conclusions}

From above data and findings it could be concluded that renal tubular functions of sickle cell anemia is impaired. The most of the urine biochemical parameters vary significantly from the normal indicating glomerular dysfunction may be due to glomerular damage, tubular damage and nephritis.

Limitations of our study: Various factors affecting on random urine sample collections such as hydration status, environmental factors (seasonal variations), and physical exercise like travelling, exact time of random urine collection and gender difference were not considered.

\section{Acknowledgement}

The authors are grateful to Board of College and University Development University of Pune for financial support. Corresponding author is thankful to DSTPURSE for partial financial support. We are thankful to Thalassemia Center, Jankalyan Blood Bank, Nashik and Mr. Narendra Manwar, Department of Zoology, University of Pune for their co-operation throughout the research work. 
Citation: Andhale RB, Sangita Lodha, Wankhade V (2013) Renal Physiological Status of Sickle Cell Anemic Patients, District Amravati, MS India. J Blood Disorders Transf 5: 188. doi: 10.4172/2155-9864.1000188

Page 3 of 3

\section{References}

1. Walker TM, Hambleton IR, Serjeant GR (2000) Gallstones in sickle cell disease observations from The Jamaican Cohort study. J Pediatr 136: 80-85.

2. Walker TM, Beardsall K, Thomas PW, Serjeant GR (1996) Renal length in sickle cell disease: observations from a cohort study. ClinNephrol 46: 384-388.

3. WHO (2006) Sickle-Cell disease and other haemoglobin disorder.

4. Diggs LW (1973) Anatomic lesions in sickle cell disease. In: Abrahanson $\mathrm{H}$ Berles JF, wethers DL (Eds.), Sickle Cell Disease; Diagnosis, Management, Education and Research St. Louis, Missouri, 189-229.

5. Thomas AN, Pattison C, Serjeant GR (1982) Causes of death in sickle-cell disease in Jamaica. Br Med J (Clin Res Ed) 285: 633-635.

6. Seeler RA (1972) Deaths in children with sickle cell anemia. A clinical analysis of 19 fatal instances in Chicago. ClinPediatr (Phila) 11: 634-637.

7. Powars D, Overturf G, Weiss J, Lee S, Chan L (1981) Pneumococcal septicemia in children with sickle cell anemia. Changing trend of survival. JAMA 245: 1839-1842.

8. Pearson HA (1986) A neonatal program for sickle cell anemia. AdvPediatr 33 381-400.

9. John AB, Ramlal A, Jackson H, Maude GH, Sharma AW, et al. (1984) Prevention of pneumococcal infection in children with homozygous sickle cell disease. B Med J (Clin Res Ed) 288: 1567-1570.

10. Grover R, Shahidi S, Fisher B, Goldberg D, Wethers D (1983) Current sickle cell screening program for newborns in New York City, 1979-1980. Am J Public Health 73: 249-252.

11. Gaston MH, Verter JI, Woods G, Pegelow C, Kelleher J, et al. (1986) Prophylaxis with oral penicillin in children with sickle cell anemia. A randomized trial. N Engl J Med 314: 1593-1599.

12. Gupta AK, Kirchner KA, Nicholson R, Adams JG 3rd, Schechter AN, et al (1991) Effects of alpha-thalassemia and sickle polymerization tendency on the urine-concentrating defect of individuals with sickle cell trait. J Clin Invest 88 1963-1968.

13. Corwin HL (1996) Urinalysis in Diseases of the Kidney. (6th Edn.), Boston Little Brown and Company, USA, 295-306.

14. European Confederation of Laboratory Medicine (2000) European urinalysis guidelines. Scand J Clin Lab Invest Suppl 231: 1-86.

15. Skobe C (2004) The basics of specimen collection and handling of urine testing. Lab Notes 14: 2.

16. Eldor A, Maclouf J, Lellouche F, Ben-Yashar V, Barenholz Y, et al. (1993) A chronic hypercoagulable state and life-long platelet activation in beta thalassemia major. Southeast Asian J Trop Med Public Health 24 Suppl 1: 92-95.

17. Oser BL (1976) Hawk's Physiological Chemistry. (14th Edn.), Tata McGraw-Hill Publishing Company Ltd, USA.

18. Wankhade V,Andhale RB, Lodha S (2013) Microscopic investigations of urine of sickle cell anemic patients. International journal of zoology and research 3: 1-6.

19. Wankhade V, Andhale RB, Lodha S (2012) Prediction of Physiological Status of Sickle Cell Anemic Patients by Quantitative Observations of Microscopic Components of Urine. Trends in Medical Research 8: 27-31.

20. Guasch A, Cua M, Mitch WE (1996) Early detection and the course of glomerular injury in patients with sickle cell anemia. Kidney Int 49: 786-791.

21. Powars DR, Chan LS, Hiti A, Ramicone E, Johnson C (2005) Outcome of sickle cell anemia: a 4-decade observational study of 1056 patients. Medicine (Baltimore) 84: 363-376.

22. Allon M (1990) Renal abnormalities in sickle cell disease. Arch Intern Med 150 501-504.

23. Serjeant GR, Higgs DR, Hambleton IR (2007) Elderly survivors with homozygous sickle cell disease. N Engl J Med 356: 642-643.

24. Aldudak B, KarabayBayazit A, Noyan A, Ozel A, Anarat A, et al. (2000) Renal function in pediatric patients with beta-thalassemia major. PediatrNephrol 15: 109-112.

Citation: Andhale RB, Sangita Lodha, Wankhade V (2013) Renal Physiological Status of Sickle Cell Anemic Patients, District Amravati, MS India. J Blood Disorders Transf 5: 188. doi: 10.4172/2155-9864.1000188
25. Serjeent GR (1992) Sickle cell Disease. Oxford University Press, Oxford, 261-281.

26. Mapp E, Karasick S, Pollack H, Wechsler RJ, Karasick D (1987) Uroradiological manifestations of S-hemoglobinopathy. SeminRoentgenol 22: 186-194.

27. De Jong PE, de Jong-van den Berg LT, Sewrajsingh GS, Schouten H, Donker AJ, et al. (1981) Beta-2-microglobulin in sickle cell anaemia. Evidence of increased tubular reabsorption. Nephron 29: 138-141.

28. Falk RJ, Jennette JC (1994) Renal disease. In: Embury SH, Hubbell RP, Mohandas N \& Steinberg MH (Eds.), Sickle Cell Disease: Basic Principles and Clinical Practice. Raven press, New York, USA, 673-680.

29. Strauss J, Zilleruelo G, Abitbol C (1986) The kidney and hemoglobin S. Nephron 43: 241-245.

30. Aoki RY, Saad ST (1990) Microalbuminuria in sickle cell disease. Braz J Med Biol Res 23: 1103-1106.

31. Nissenson AR, Port FK (1989) Outcome of end-stage renal disease in patients with rare causes of renal failure. I. Inherited and metabolic disorders. Q J Med 73: $1055-1062$.

32. Scheinman JI (1994) Sickle cell nephropathy. In: Holliday M, Barratt TM, Avner ED (Eds.), Pediatric Nephrology, Baltimore, Williams \& Wilkins, USA, 908-919.

33. Powars DR, Elliott-Mills DD, Chan L, Niland J, Hiti AL, et al. (1991) Chronic renal failure in sickle cell disease: risk factors, clinical course, and mortality. Ann Intern Med 115: 614-620.

34. Platt OS, Brambilla DJ, Rosse WF, Milner PF, Castro O, et al. (1994) Mortality in sickle cell disease. Life expectancy and risk factors for early death. $\mathrm{N}$ Engl J Med 330: 1639-1644

35. Sklar AH, Campbell H, Caruana RJ, Lightfoot BO, Gaier JG, et al. (1990) A population study of renal function in sickle cell anemia. Int J Artif Organs 13 231-236.

36. Allon M, Lawson L, Eckman JR, Delaney V, Bourke E (1988) Effects of nonsteroidalantiinflammatory drugs on renal function in sickle cell anemia. Kidney Int 34: 500-506.

37. De Jong PE, de Jong-Van Den Berg TW, Sewrajsingh GS, Schouten H, Donke AJ, et al. (1980) The influence of indomethacin on renal haemodynamics in sickle cell anaemia. ClinSci (Lond) 59: 245-250.

38. Tejani A, Phadke K, Adamson O, Nicastri A, Chen CK, et al. (1985) Rena lesions in sickle cell nephropathy in children. Nephron 39: 352-355.

39. de Jong PE, Statius van Eps LW (1985) Sickle cell nephropathy: new insights into its pathophysiology. Kidney Int 27: 711-717.

40. Pham PT, Pham PC, Wilkinson AH, Lew SQ (2000) Renal abnormalities in sickle cell disease. Kidney Int 57: 1-8

41. Guasch A, Navarrete J, Nass K, Zayas CF (2006) Glomerular involvement in adults with sickle cell hemoglobinopathies: Prevalence and clinical correlates of progressive renal failure. J Am SocNephrol 17: 2228-2235.

42. Falk RJ, Scheinman J, Phillips G, Orringer E, Johnson A, et al. (1992) Prevalence and pathologic features of sickle cell nephropathy and response to inhibition of angiotensin-converting enzyme. N Engl J Med 326: 910-915. 